\title{
半導体超格子の精密構造制御と光物性
}

\section{Precise Control of Structures of Semiconductor Superlattices and Related Optical Properties}

\author{
中山正昭* \\ Masaaki NAKAYAMA
}

\begin{abstract}
Key Words: Semiconductor Superlattice, Monolayer Control, Optical Properties, Molecular Beam Epitaxy, Mini-Brillouin Zone, Folded Phonon Mode, Miniband Structure, Raman Scattering, Photoreflectance
\end{abstract}

\section{1. 緒 言}

半導体超格子 (semiconductor superlattice) とは、異なる種 類の半導体超薄膜の周期積層構造の総称であり、1970 年に 当時 IBM 社の江崎玲於奈博士と R.Tsu 博士によって提案さ れて以来 ${ }^{1)}$ 、電子・正孔波動関数に対する量子効果による 物性制御と新奇な機能が注目され、半導体物理学.工学の 先端を切り拓いてきた物質系である ${ }^{2,3)}$ 。また、ナノテクノ ロジーの嗃矢の一つとして、その概念は半導体だけでなく 物質科学全般に広く浸透している。

超格子の物性と機能において、最も重要な概念がミニブ リルアンゾーン (mini-Brillouin zone) の形成である。A/B 超 格子では、 $\mathrm{A}$ 層の層厚を $d_{\mathrm{A}} 、 \mathrm{~B}$ 層の層厚を $d_{\mathrm{B}}$ とすると、積 層方向 $(z$ 方向と定義する) にナノメートルオーダーの人 工的周期 $\left(D=d_{\mathrm{A}}+d_{\mathrm{B}}\right)$ が生じる。この超格子周期は、バル ク結晶の格子定数 $\left(a_{0}: 0.4 \sim 0.7 \mathrm{~nm}\right.$ 程度 $)$ よりも長いた めに、積層方向のブリルアンゾーンの領域 $\left(-\pi / D \leq k_{z} \leq \pi / D\right)$ は、バルク結晶よりも顕著に小さいものとなり、これをミ ニブリルアンゾーンと呼ぶ。ミニブリルアンゾーンの形成 によって、電子・正孔やフォノンのエネルギー分散関係が 折り返されてバルク結晶とは全く異なったものとなり、超 格子特有の物性と機能性が生じる。したがって、結晶成長 プロセスにおいて、層厚の制御が不十分であれば、ミニブ リルアンゾーンは乱れたものとなり、物性と機能性の発現 が不十分なものとなる。

超格子の結晶成長に関しては、分子線エピタキシー (molecular beam epitaxy : MBE) 法と有機金属気相エピタキ シー (metal-organic vapor phase epitaxy : MOVPE) 法が 1970 年代から用いられてきた。MBE 法と MOVPE 法は、とも に高度な結晶成長法であるが、精密層厚制御という観点 において当初は不十分なものであった。ここで、精密層 厚制御とは、結晶構造の最小単位である「モノレイヤー」
(monolayer：ML)、具体的には、GaAs 結晶の場合は主軸方 向の As-Ga-As スタッキングの間隔 $\left(a_{0} / 2=0.283 \mathrm{~nm}\right)$ を単 位として「デジタル制御」することを意味する。精密層厚 制御が出来なかった最大の理由は、結晶成長過程を ML 単 位でリアルタイムにモニターする手法がなかったためであ る。

本稿では、まず、筆者らが世界に先駆けて開発した MBE 法による半導体超格子の ML 制御技術について述べる。そ して、ミニブリルアンゾーン形成が最もドラマティック に発現する超格子の折り返しフォンモード (folded phonon mode) とミニバンド構造 (miniband structure) について、ML 制御された試料を対象とした筆者らの光物性研究の成果に ついて解説する。

\section{MBE 法によるモノレイヤー制御}

一般的な MBE 装置には、試料の表面構造を観察するた めに反射型高速電子線回折 (reflection high energy electron diffraction: RHEED) 装置が備え付けられている。Fig. 1(a) は、MBE 法による GaAs 結晶成長中に観測される典型的な RHEED パターンを示している。表面に 3 次元的な凹凸が ある場合はラウ工斑点となるが、2 次元平坦表面では、図 のように棒状の回折パターン（ストリークパターン： streak pattern）が観測される。MBE 成長の場合、緩衝層の成長段 階でこのストリークパターン、即ち、表面の 2 次元平坦性 を確認して、超格子の結晶成長をスタートする。これが、 常識的な RHEED の利用法であった。

1983 年に、Neave らは、表面科学の観点から MBE 成長 中に生じる RHEED 強度の振動パターンが、2 次元的 layerby-layer 成長を反映していると解釈した ${ }^{4)}$ 。筆者らは、その 研究成果を積極的に MBE 成長プロセスに応用することを 考案し（NeaveらはMBE 成長への応用には全く言及してい ない)、1984 年に、極限層厚である $1 \mathrm{ML} の(\mathrm{GaAs})_{1} /(\mathrm{AlAs})_{1}$

*大阪市立大学大学院工学研究科電子情報系専攻（558-8585 大阪市住吉区杉本 3-3-138）

Department of Physical Electronics and Informatics, Graduate School of Engineering, Osaka City University (3-3-138 Sugimoto, Sumiyoshi-ku, Osaka, Oxaka, 558-8585 Japan) 


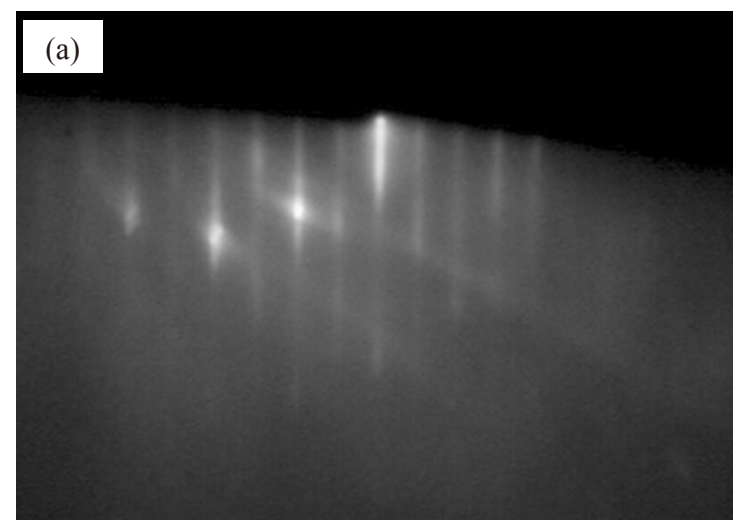

(b)

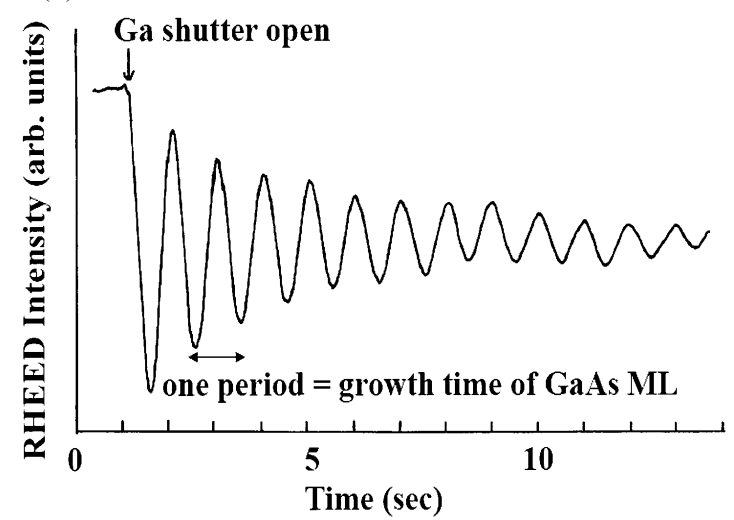

Fig. 1 (a) Typical RHEED pattern in the MBE growth of GaAs. (b) Oscillation pattern of the RHEED intensity in the MBE growth of GaAs.

超格子の結晶成長に初めて成功した ${ }^{5)}$ 。Fig. 1(b) は、GaAs 結晶の MBE 成長中に観測される RHEED 強度の振動パター ンを示している。Ga セルのシャッターを開くと同時に、強 度振動が生じる。尚、GaAs 系の MBE 成長の場合は、As フラックスは絶えず照射している。観測される振動パター ンの 1 周期が $\mathrm{GaAs}$ の $1 \mathrm{ML}$ の成長時間に対応する。したがっ て、RHEED 強度の振動パターンに同期してセルのシャッ ターの開閉を制御すれば、ML 単位での精密層厚制御が可 能となる。このことは気づけば簡単なことであり、正に 「コロンブスの卵」的発想と言える。RHEED 強度の時間的 減衰は、2 次元表面の乱れによるものであるが、成長中断 を行うと、表面原子のマイグレーションにより平坦性が回 復し、それを反映して RHEED 強度も回復する。したがっ て、例えば $(\mathrm{GaAs})_{m} /(\mathrm{AlAs})_{n}$ 超格子を結晶成長する場合は、 $\mathrm{GaAs}$ 層を $m \mathrm{ML}$ 成長した後に、成長を中断して $(5 \sim 10$ 秒 $)$ 良好な 2 次元表面状態を形成し、AlAs 層を $n \mathrm{ML}$ 成長して 再び成長中断を行う。このプロセスの繰り返しによって、 ML 制御超格子の結晶成長を行うことができる。

Fig. 2 は、 $(\mathrm{GaAs})_{1} /(\mathrm{AlAs})_{1}$ 超格子の $[00 L]$ 方向の X 線回 折パターンを示している5)。閃亚鉛鉱構造の本来の回折で ある $L=2$ を中心として、 $L=1$ と $L=3$ に超格子特有の回

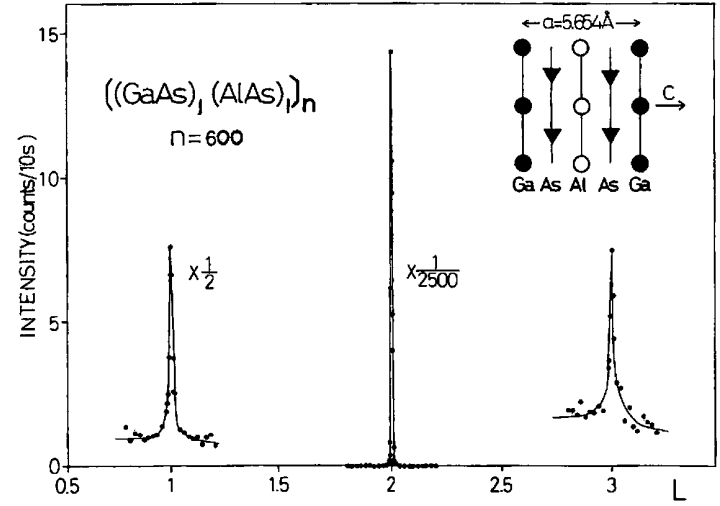

Fig. 2 X-ray diffraction pattern of a $(\mathrm{GaAs})_{1} /(\mathrm{AlAs})_{1}$ superlattice along the $[00 L]$ direction.

折（衛星反射と呼ばれる）が明確に現れている。 $L=1$ と $L$ $=3$ の回折は、バルク結晶では禁制であるが、(GaAs) $1 /(\mathrm{AlAs})_{1}$ 超格子ではバルク結晶の 2 倍 (2 ML)の人工的周期性が $[00 L]$ 方向に形成されるために観測される。このようにして、極 限層厚である $(\mathrm{GaAs})_{1} /(\mathrm{AlAs})_{1}$ 超格子が作製できていること が厳密に証明された。ML制御された超格子の X 線構造解 析に関しては、文献 6)に詳細を報告している。筆者らの 研究成果の報告の後、上記の RHEED 強度振動を利用した ML 層厚制御は広く普及し、超格子や量子井戸構造の研究 が大きく進展する一因となった。

本章の最後に、RHEED 強度振動の $\mathrm{Al}_{x} \mathrm{Ga}_{1-x} \mathrm{As}$ などの混晶 への応用について述べる。混晶は、エレクトロニクス材料 として広く用いられているが、混晶の物性を決定する混晶 比の評価に困難さがあった。しかし、以下で述べる方法に より、結晶成長中に混晶比を評価、もしくは、制御するこ とが可能となった。 $\mathrm{Al}_{x} \mathrm{Ga}_{1-x} \mathrm{As}$ を例にすると、まず、GaAs の $1 \mathrm{ML}$ の成長時間 $\left(T_{\mathrm{GaAs}}\right)$ を RHEED 強度振動から求める。 次に、 $\mathrm{Ga}$ セルと $\mathrm{Al}$ セルの両方のシャッターをオープンし て、 $\mathrm{Al}_{x} \mathrm{Ga}_{1-x} \mathrm{As}$ の成長時間 $\left(T_{\mathrm{AlGaAs}}\right)$ を同じく RHEED 強度振 動から測定する。混晶比 $x$ は、上記の成長時間から、

$$
x=\left(1 / T_{\mathrm{AlGaAs}}-1 / T_{\mathrm{GaAs}}\right) /\left(1 / T_{\mathrm{AlGaAs}}\right)
$$

と求まり、結晶成長中にリアルタイムで混晶比が評価でき る。このことも、RHEED 強度振動の結晶成長プロセスへ の応用として大きな意義がある。

\section{3. モノレイヤー制御超格子における折り返しフォノンモード}

超格子におけるミニブリルアンゾーン形成は、フォノン モードを劇的に変化させる。Fig. 3 は、(001) 面 $(\mathrm{GaAs})_{4} /$ $(\mathrm{AlAs})_{4}$ 超格子の縦型フォノン分散関係（実線）の計算結果 を示している7)。破線は、GaAs と AlAs のバルク結晶のフォ ノン分散関係を示している。 $(\mathrm{GaAs})_{4} /(\mathrm{AlAs})_{4}$ 超格子の場合、 積層方向 $(z$ 方向) に $8 \mathrm{ML}$ の長周期性があるために、ミニ 


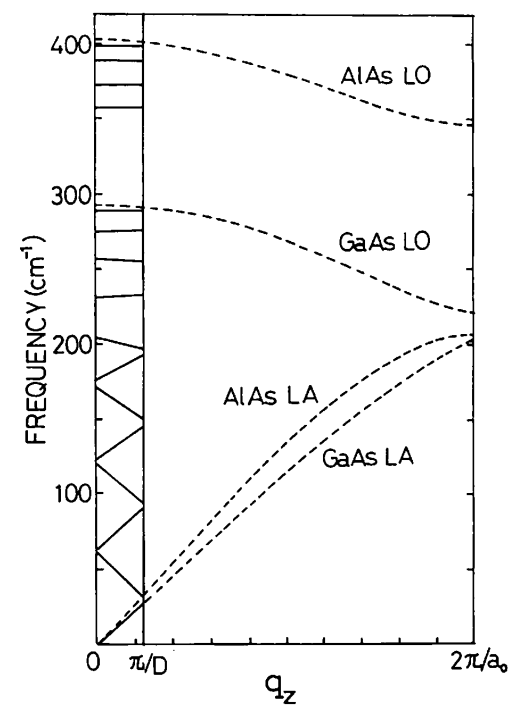

Fig. 3 Calculated dispersion relations of the LA and LO phonons in a $(\mathrm{GaAs})_{4} /(\mathrm{AlAs})_{4}$ superlattice and bulk crystals of GaAs and AlAs.

ブリルアンゾーン端 $\left(q_{z}=\pi / D\right)$ はバルク結晶のブリルアン ゾーンの $1 / 8$ の位置に形成され、フォノン分散が折り返さ れる。この折り返し効果 (zone-folding effect)によって、超 格子特有の新たなフォノンモードが生成される。 $(\mathrm{GaAs})_{4} /$ $(\mathrm{AlAs})_{4}$ 超格子には、積層方向に $8 \times 2=16$ のフォノンモー ド自由度があり、その内の 8 モードが縦音響 (longitudinal acoustic: LA) フォノンに、残りの 8 モードが (longitudinal optical: LO) フォノンに分配される。超格子の LA フォノン 分散関係は、GaAs と AlAs のバルク結晶の分散関係を平均 化したものを、ミニブリルアンゾーンにおいて単純に折り 返した状態である。これを、折り返しLAフォノンモード (folded LA-phonon mode) と呼ぶ。この現象は、2つの LA フォ ノン分散の振動数領域が重なっているためである。一方、 LO フォノン分散関係は、LA フォノンとは大きく異なって おり、量子井戸構造の量子化電子 ·正孔状態に類似してい る。LOフォノンの場合、 $\mathrm{GaAs}$ と $\mathrm{AlAs}$ の振動数領域が重 なっていないために、それぞれの LO フォノンは自己主張 し、GaAs 型LO フォノンモードと AlAs 型LO フォノンモー ドが形成される。GaAs 型LOフォノンモードは GaAs 層に、 $\mathrm{AlAs}$ 型LOフォノンモードは AlAs 層に強く閉じ达められ た状態となっている。このようなLOフォノンモードを、 閉じ込めLOフォノンモード (confined LO-phonon mode) と 呼ぶ。このように、超格子にはフォノンの制御という観点 においても興味深い。本稿では、ラマン散乱分光法 (Raman scattering spectroscopy)による折り返しLAフォノンモード に関する研究成果に焦点を絞って解説する ${ }^{8)}$ 。

ここで、フォノンラマン散乱を解釈するための、ラマン 散乱選択則について概略的に述べる。入射光の偏光べクト

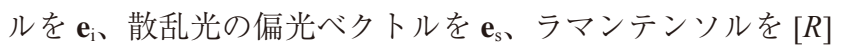

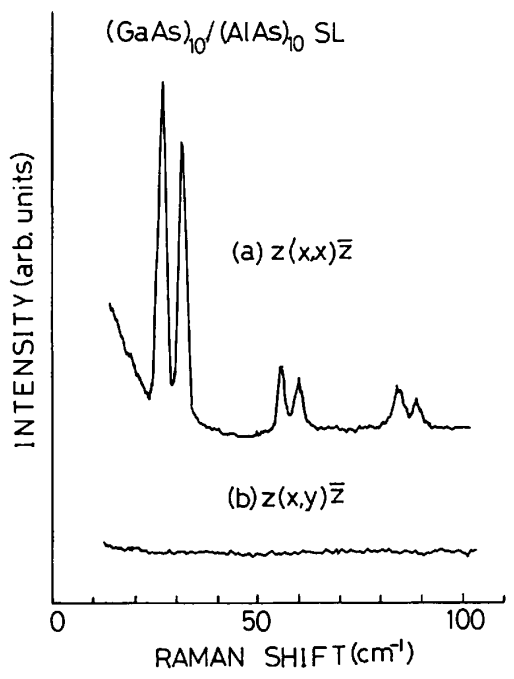

Fig. 4 Raman spectra of a $(\mathrm{GaAs})_{10} /(\mathrm{AlAs})_{10}$ superlattice in the frequency range of the acoustic phonon in (a) $z(x, x) \bar{z}$ and (b) $z(x, y) z$ configurations at room temperature.

とすると、ラマン散乱は、次式の条件で許容となる9)。

$$
\mathbf{e}_{\mathrm{i}}[R] \mathbf{e}_{\mathrm{s}} \neq 0
$$

$\mathrm{GaAs}$ などの閃亜鉛鉱構造（点群： $\mathrm{T}_{\mathrm{d}}$ ）の半導体によって構 成された超格子は、積層方向の超周期性のために正方晶系 の点群 $\mathrm{D}_{2 \mathrm{~d}}$ の対称性となる。点群 $\mathrm{D}_{2 \mathrm{~d}}$ のラマンテンソルは、 以下のように表される ${ }^{9}$ 。

$$
\begin{aligned}
& \left(\begin{array}{lll}
a & 0 & 0 \\
0 & a & 0 \\
0 & 0 & b
\end{array}\right)\left(\begin{array}{lll}
0 & d & 0 \\
d & 0 & 0 \\
0 & 0 & 0
\end{array}\right)\left(\begin{array}{lll}
0 & 0 & 0 \\
0 & 0 & e \\
0 & e & 0
\end{array}\right)\left(\begin{array}{lll}
0 & 0 & e \\
0 & 0 & 0 \\
e & 0 & 0
\end{array}\right) \\
& \begin{array}{llll}
\mathrm{A}_{1} & \mathrm{~B}_{2}(z) & \mathrm{E}(x) & \mathrm{E}(y)
\end{array}
\end{aligned}
$$

括弧中の $x 、 y 、 z$ は、フォノンの分極方向を示している。(001) 面基板上に結晶成長された超格子の場合、後方散乱配置で は、波数ベクトル選択則から、観測されるフォノンの波数 ベクトル方向（伝播方向）は、 $\boldsymbol{q} / / z=[001]$ であり、縦 $\left(\mathrm{A}_{1}\right.$ と $\mathrm{B}_{2}$ ) モードは [001] 方向に振動し、横 $(\mathrm{E})$ モードは [100] と [010]方向に振動する。各フォノンモードの偏光選択則は、 式 (2) に基づく計算から、 $\mathrm{A}_{1}$ モードが $z(x, x) \bar{z}$ もしくは $z(y$, $y) \bar{z} 、 \mathrm{~B}_{2}$ モードが $z(x, y) \bar{z}$ もくは $z(y, x) \bar{z}$ で観測され、 $\mathrm{E} モ$ ドは禁制となる。尚、上記の観測条件の表記は、入射光方 向（大射光の偏光方向、散乱光の偏光方向）散乱光方向を 意味している。

折り返し LA フォノンモードの最初の観測結果は、1980 年にColvardらによって報告された ${ }^{10)}$ 。筆者らは、ML 制 御された $(\mathrm{GaAs})_{m} /(\mathrm{AlAs})_{m}$ 超格子を試料として、超格子の フォノンモードの全貌を明らかにした ${ }^{8)}$ 。Fig. 4 は、(001) 面 $(\mathrm{GaAs})_{10} /(\mathrm{AlAs})_{10}$ 超格子における室温での音響フォノン 
スマートプロセス学会誌

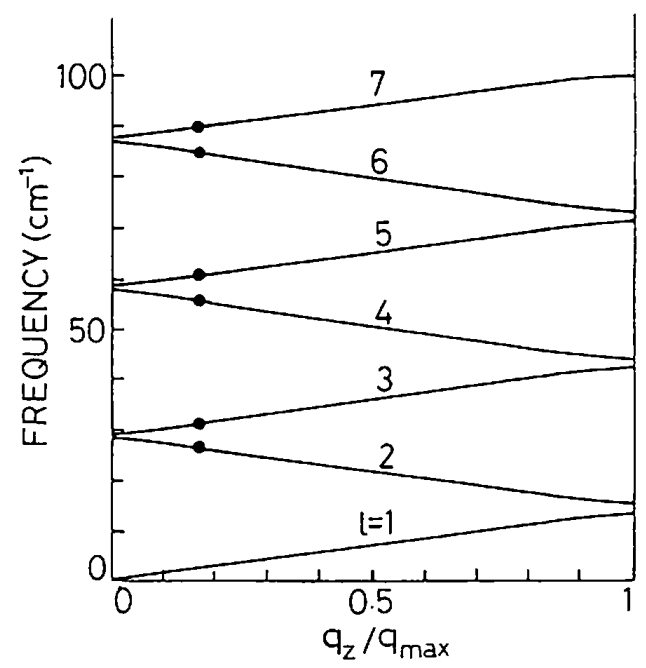

Fig. 5 Observed frequencies of the folded LA phonon modes (solid circles) and calculated dispersion relations (solid lines) with use of Eq. (4) in the $(\mathrm{GaAs})_{10} /(\mathrm{AlAs})_{10}$ superlattice.

振動数領域のラマン散乱スペクトル（後方散乱配置）を示 している ${ }^{8)}$ 。30、60、90 $\mathrm{cm}^{-1}$ 近傍のダブレットバンドが、 LA フォノンの 1 次、 2 次、3 次の折り返しモードによるラ マン散乱である。全ての折り返しモードは、 $z(x, x) \bar{z}$ 配置 で観測されており、上で述べたラマン散乱選択則から $\mathrm{A}_{1}$ 対称性であることが分かる。この様な折り返しモードのラ マン散乱は、層厚が $2 \mathrm{ML}(0.565 \mathrm{~nm})$ という極薄膜 $(\mathrm{GaAs})_{2}$ / $(\mathrm{AlAs})_{2}$ 超格子においても明確に観測されることを実証して いる ${ }^{11)}$ 。

音響フォノン折り返しモードを解析するモデルとして、 連続弾性体モデル (elastic continuum model) がある。この場 合、物質中の音速を $V$ 、フォノン波数ベクトルを $q$ とすると、 分散関係を $\omega=v q$ で近似する。超格子を 2 種類の弾性体か らなる周期積層構造と仮定し、音波の伝播に関する波動方 程式を解くと、LA フォノン分散関係は、次式によって与 えられる ${ }^{8,10,12)}$ 。

$$
\begin{aligned}
& \cos \left(q_{z} D\right)=\cos \left(\frac{\omega d_{1}}{V_{1}}\right) \cos \left(\frac{\omega d_{2}}{V_{2}}\right) \\
& -\frac{1}{2}\left(\frac{V_{2} \rho_{2}}{V_{1} \rho_{1}}+\frac{V_{1} \rho_{1}}{V_{2} \rho_{2}}\right) \sin \left(\frac{\omega d_{1}}{V_{1}}\right) \sin \left(\frac{\omega d_{2}}{V_{2}}\right)
\end{aligned}
$$

ここで、 $d_{i}$ が層厚、 $D\left(=d_{1}+d_{2}\right)$ が周期、 $\rho_{i}$ が密度を意味し ている。Fig. 5 は、式 (4) に基づいて計算した $(\mathrm{GaAs})_{10} /$ $(\mathrm{AlAs})_{10}$ 超格子の [001] 方向 LA フォノン分散関係と、Fig. 4 のラマン散乱スペクトルから得られたLA フォノン折り 返しモードの振動数を示している ${ }^{8)} 。 q_{\max }$ は超格子のミニ ブリルアンゾーン端の波数ベクトル $(\pi / D 、 D=20 \mathrm{ML}=5.65$ $\mathrm{nm})$ を意味しており、バルク結晶のブリルアンゾーンの
第 2 巻 第 5 号（2013 年 9 月）

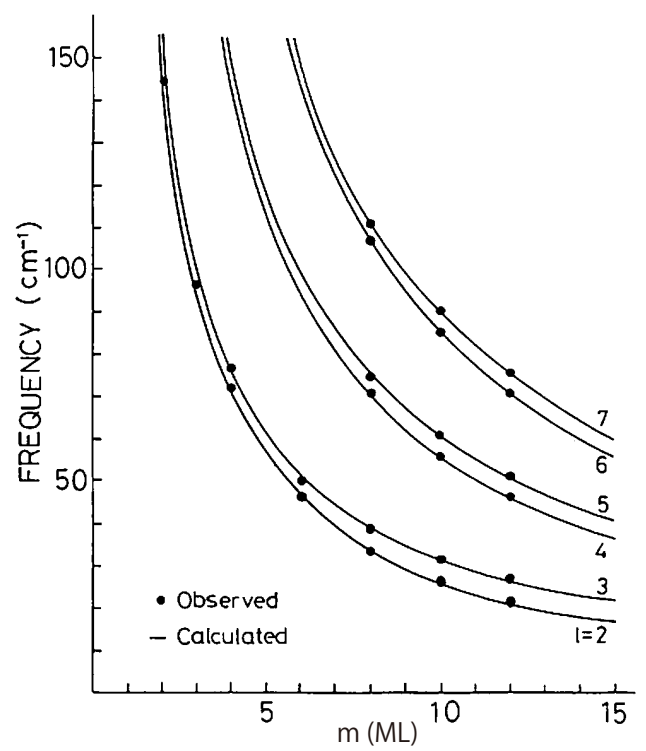

Fig. 6 Observed frequencies of the folded LA phonon modes and the calculated frequencies with use of Eq. (4) as a function of ML thickness in $(\mathrm{GaAs})_{m} /(\mathrm{AlAs})_{m}$ superlattices.

$1 / 20$ に相当する。後方散乱配置における測定では、ラマン 散乱に寄与するフォノンの波数べクトルの大きさは、波数 ベクトル選択則から次式で定義される。

$$
q_{z}=4 \pi n / \lambda_{\mathrm{i}}
$$

ここで、 $n$ は超格子の屈折率 $\left(n=\left(n_{1} d_{1}+n_{2} d_{2}\right) /\left(d_{1}+d_{2}\right)\right.$ : 層厚 平均)、 $\lambda_{\mathrm{i}}$ は入射光波長である。バルク結晶では、 $q_{z} \approx 0$ と 近似できるが、超格子の場合、ミニブリルアンゾーンの波 数領域が小さいために $q_{z}$ を無視することができない。超格 子の屈折率として、 $\lambda_{\mathrm{i}}=514.5 \mathrm{~nm}$ における GaAs と $\mathrm{AlAs}$ バ ルク結晶の屈折率 (4.22 と 3.31) の上記層厚平均を採用す ると、 $q_{z} / q_{\max }=0.165$ という值が得られる。Fig. 5 から明ら かなように、連続弾性体モデルに基づく計算結果は、フィッ ティングパラメータを全く用いずに実験結果を非常に良く 説明している。ここに、ML 制御の大きな意味があり、極 めて精密に超格子のフォノン物性を明らかにすることがで きる。

Fig. 6 は、 $(\mathrm{GaAs})_{m} /(\mathrm{AlAs})_{m}$ 超格子の [001] 方向 LA フォ ノン折り返しモード振動数の層厚依存性の実験結果（黒丸） と式 (4)による計算結果 (実線) を示している ${ }^{8)}$ 。 $2 \sim 12$ MLの層厚において、実験結果は計算結果と完全に一致し ている。このことは、層厚が $2 \mathrm{ML}$ という極薄膜超格子まで、 連続弾性体モデルが適用できることを示している。連続弾 性体モデルは、超格子の構成物質の音速と密度が既知であ るならば、どのような超格子系に対しても適用できるため に、折り返しLAフォノンモードに関する解析の基準モデ ルとなった。 
超格子のフォノンに関する研究の近年の進展として、コ ヒーレントフォノンを挙げることができる。コヒーレント フォノンとは、フォノンの振動周期よりも短いレーザーパ ルス（通常は $50 \sim 100 \mathrm{fs}$ 程度）で励起することにより生成 された位相の揃ったフォノン（時間と空間の両方において） に相当する。折り返しコヒーレントLAフォノンモードは、 1994 年に、時間分解ポンプ・プローブ分光法 (time-resolved

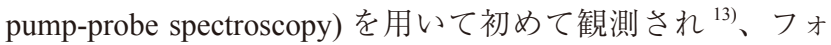
ノンダイナミクスの観点から盛んに研究が行われた。また、 LO フォノンは、本来がテラヘルツ振動数領域であるため に $(\mathrm{GaAs}$ の場合、8.8 THz)、テラヘルツ電磁波発生源とし て注目されていたが、バルク結晶では極めて微弱な電磁波 しか発生できなかった。その最大の理由は、バルク結晶の 場合、コヒーレントLOフォノンによる動的双極子モーメ ントが並進対称性によって打ち消されるためである。言い 換えれば、並進対称性が破れている表面領域しか電磁波を 放射できない。一方、超格子や多重量子井戸構造での閉じ 込めLOフォノンモードの場合、各へテロ界面で対称性が 破れている。筆者らはこのことに着目し、閉じ込めコヒー レントLOフォノンモードから高強度の単色性テラヘルツ 電磁波が発生することを明らかし、その増強機構に関する 研究を展開している ${ }^{14-17) 。}$

\section{4. モノレイヤー制御超格子におけるミニバンド構造}

超格子におけるミニブリアンゾーンにおいて、電子・正 孔量子化状態のミニバンドが形成される。 A/B 超格子 (A が量子井戸層、 $\mathrm{B}$ が障壁層）のミニバンド構造は、有効質 量近似 (effective mass approximation)に基づくと次式で与え られる ${ }^{18)}$ 。

$$
\begin{aligned}
& \cos \left(k_{z} D\right)=\cos \left(k_{\mathrm{A}} d_{\mathrm{A}}\right) \cosh \left(k_{\mathrm{B}} d_{\mathrm{B}}\right) \\
& +1 / 2\left(\frac{m_{\mathrm{A}}{ }^{*} k_{\mathrm{B}}}{m_{\mathrm{B}}{ }^{*} k_{\mathrm{A}}}-\frac{m_{\mathrm{B}}{ }^{*} k_{\mathrm{A}}}{m_{\mathrm{A}}{ }^{*} k_{\mathrm{B}}}\right) \sin \left(k_{\mathrm{A}} d_{\mathrm{A}}\right) \sinh \left(k_{\mathrm{B}} d_{\mathrm{B}}\right) \\
& k_{\mathrm{A}}=\sqrt{2 m_{\mathrm{A}}{ }^{*} E} / \hbar, k_{\mathrm{B}}=\sqrt{2 m_{\mathrm{B}}{ }^{*}(V-E) / \hbar}
\end{aligned}
$$

式 (6)において、量子力学の教科書に記述されている一般 的な Kronig-Penney 型方程式と異なるところは、A 層と B 層の有効質量の違いを、有効質量補正として取り込んでい ることである。Fig. 7 は、 $(\mathrm{GaAs})_{10} /(\mathrm{AlAs})_{1}$ 超格子における 電子、重い正孔、及び、軽い正孔のミニバンド構造の式 (6) に基づく計算結果を示している。AlAs 層厚が極限層厚であ

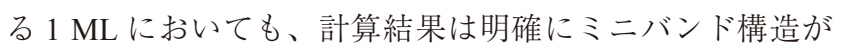
形成されることを示している。問題は、これを実際に検証 できるかどうかということである。

電子・正孔ミニバンド状態間の光学遷移は、Fig. 7 から も分かるように、積層方向の波数ベクトル $k_{z}=0$ ( $\Gamma$ 点）と $k_{z}=\pi / D$ （ミニブリルアンゾーン端、 $\pi$ 点）の 2 種類の状態

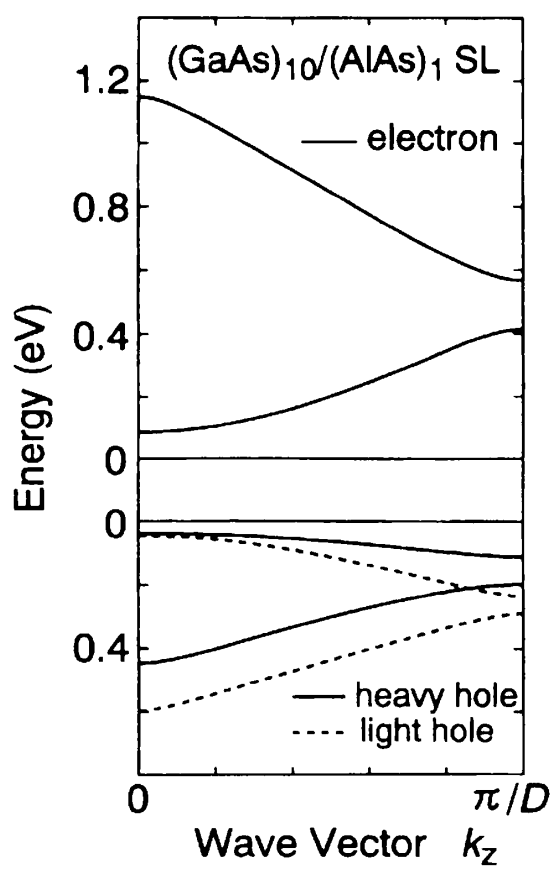

Fig. 7 Calculated miniband dispersion relations of the electron, heavy hole, and light hole in a $(\mathrm{GaAs})_{10} /(\mathrm{AlAs})_{1}$ superlattice with use of Eq. (6).

密度特異点を有している。したがって、「点と $\pi$ 点の光学 遷移を測定できれば、ミニバンド構造（ミニバンド幅）を 実験的に決定することができる。しかしながら、一般的な 発光励起分光法や光吸収分光法では、連続状態遷移のバッ クグラウンドがスペクトルに重畳するために、 $\pi$ 点の光学 遷移を検出することが困難である。筆者らは、光変調反射 分光法 (photoreflectance spectroscopy) と電場変調反射分光 法 (electroreflectance spectroscopy) を駆使して、超格子のミ ニバンド構造に関する研究を行った ${ }^{19-21)}$ 。変調分光法とは、 試料に外場（電場、圧力など）の周期的摂動を加えて、そ の摂動に同期する反射率や透過率の変調成分を検出する分 光法であり、状態密度特異点の光学遷移に対して極めて敏 感である。言い換えれば、状態密度特異点での光学遷移以 外の信号はベースラインレベルとなる。光変調反射分光法 は、半導体表面でのフェルミ準位ピニングによる表面ポテ ンシャルを光励起キャリアで変調する分光法であり ${ }^{22) 、}$ 原 理的には電場変調反射分光法に属する。

Fig. 8 は、 $77 \mathrm{~K}$ における $(\mathrm{GaAs})_{10} /(\mathrm{AlAs})_{m}$ 超格子 $(m=1$ 、 2、4 ML) の光変調反射スペクトルを示している ${ }^{21)}$ 。光学遷 移を示す $11 \mathrm{H}(11 \mathrm{~L})$ という表記は、 $n=1$ 電子と $n=1$ 重い 正孔（軽い正孔）ミニバンド間遷移を、括弧中の $\Gamma$ と $\pi$ は、 上記の $\Gamma$ 点と $\pi$ 点での遷移を意味している。光变調反射信 号から遷移エネルギーを求めるためには、信号形状解析を 行わなくてはならない。Aspnes は、電場変調反射機構に基 づいて下記の解析関数を提案し ${ }^{23)}$ 、それが広く用いられて 


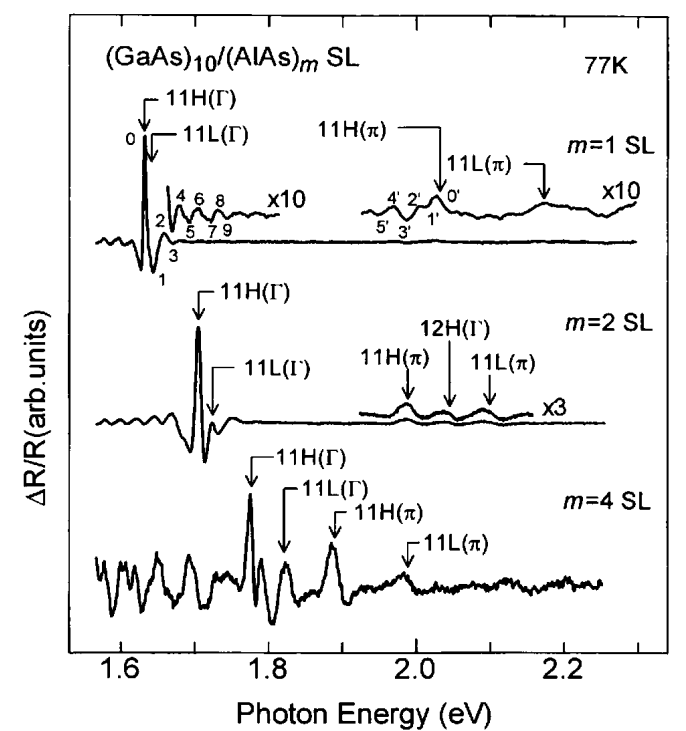

Fig. 8 Photoreflectance spectra of $(\mathrm{GaAs})_{10} /(\mathrm{AlAs})_{m}$ superlattices with $m=1,2$, and $4 \mathrm{ML}$ at $77 \mathrm{~K}$. The arrows indicate the transition energies estimated from the line-shape analysis using Eq. (7). The notations of $\mathrm{H}$ and $\mathrm{L}$ mean the heavy-hole and light-hole transitions, and those of $\Gamma$ and $\pi$ indicate the transitions at the miniBrillouin-zone center $\left(k_{z}=0\right)$ and edge $\left(k_{z}=\pi / D\right)$.

いる。

$$
\frac{\Delta R}{R}=\operatorname{Re}\left[\sum_{j=1}^{p} C_{j} \exp \left(i \phi_{j}\right)\left(E-E_{j}+i \Gamma_{j}\right)^{-m}\right]
$$

ここで、 $p$ は対象とする光学遷移信号の数であり、 $j$ はその 指数である。 $C_{j}$ が信号の振幅、 $\phi_{j}$ が位相因子、 $E_{j}$ が特異 点遷移エネルギー、「 $\Gamma_{j}$ がブロードニング因子である。また、 $m$ は状態密度の次元性により決まるパラメータで、3 次元 では $m=2.5 、 2$ 次元では 3 となる。したがって、 $C_{j} 、 \phi_{j}$ $E_{j} \Gamma_{j}$ がフィッティングパラメータとなる。Fig. 8 の矢印は、 式 (7) に基づく信号形状解析から評価した遷移エネルギー を示している。 3 種類の超格子の光変調反射スペクトルの 系統的な変化は、状態密度特異点 ( $\Gamma$ 点と $\pi$ 点) での光学 遷移が確実に観測できていることを示している。尚、「点 と $\pi$ 点の遷移エネルギーのエネルギー差が、電子と正孔の ミニバンド幅の和に相当する。

Fig. 9 は、 $(\mathrm{GaAs})_{10} /(\mathrm{AlAs})_{m}$ 超格子のミニバンド間遷移エ ネルギーの式 (6) に基づく計算結果と光変調反射スペクト ルから評価した実験結果を示している ${ }^{21)} 。 \Delta(11 \mathrm{H})$ と $\Delta(11 \mathrm{~L})$ は、 $n=1$ 電子と重い正孔のミニバンド幅の和と $n=1$ 電子 と軽い正孔のミニバンド幅の和を示している。計算では、 文献 24)に基づいて、電子と軽い正孔のバンド非放物線性 を考慮している。実験結果は、計算結果と系統的に良く一 致していることが明らかである。これにより、1MLという

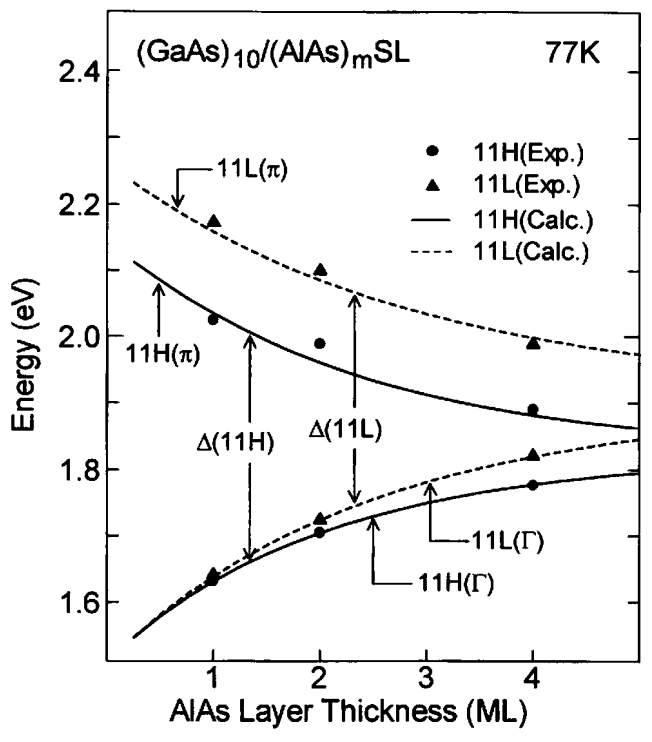

Fig. 9 AlAs-layer-thickness dependence of the energies of the $11 \mathrm{H}$ and $11 \mathrm{~L}$ transitions at $\Gamma$ and $\pi$ points in the $(\mathrm{GaAs})_{10} /(\mathrm{AlAs})_{m}$ superlattices, where the solid circles and triangles indicate the experimental results of the $11 \mathrm{H}$ and $11 \mathrm{~L}$ transitions. The solid and dashed lines indicate the calculated results using Eq. (6).

極限層厚の障壁層を有する $(\mathrm{GaAs})_{10} /(\mathrm{AIAs})_{1}$ 超格子におい ても、Fig. 7 に示したミニバンド構造が形成されているこ とが実証された。

次に、ミニバンド有効質量の分光学的評価について述べ る。Fig. 8 の $(\mathrm{GaAs})_{10} /(\mathrm{AIAs})_{1}$ 超格子の光変調反射スペクト ルに着目すると、 $11 \mathrm{H}(\Gamma)$ と $11 \mathrm{H}(\pi)$ 遷移との間のエネルギー 領域に 2 組の振動構造が観測される。一つは、 $11 \mathrm{H}(\Gamma)$ から 高エネルギー側への振動、もう一つが $11 \mathrm{H}(\pi)$ から低エネ ルギー側への振動である。尚、 $11 \mathrm{H}(\Gamma)$ の低エネルギー側の 振動構造は、 $\mathrm{GaAs}$ 基板と超格子の間にある $\mathrm{GaAs}$ 緩衝層の 吸収端 $(1.51 \mathrm{eV})$ に起因する。この様な振動構造は、FranzKeldysh 振動と呼ばれ、バンド間遷移に対する電場効果に 起因するものであり、バルク半導体では状態密度特異点の 光学遷移に関して詳細に研究されている ${ }^{25) 。 ~}$

Franz-Keldysh 振動の $v$ 番目のピークもしくはディップの エネルギー $\left(E_{v}\right)$ は、文献 25$)$ の理論に基づくと、3 次元の 場合、次式によって決定される。

$$
E_{v}=E_{0} \pm \hbar \theta\left[\frac{3 \pi}{4}\left(v-\frac{1}{2}\right)\right]^{2 / 3}, \quad \hbar \theta=\left[\frac{(e F \hbar)^{2}}{2|\mu|}\right]^{1 / 3}
$$

ここで、 $E_{0}$ はある特異点の遷移エネルギー、Fは電場強 度、 $\mu$ は電場方向の電子・正孔換算有効質量である。また、 $+(-)$ 符号は $\Gamma(\pi)$ 点での振動に対応している。式 (8)の の定義から明らかなように、Franz-Keldysh 振動のエネル ギーは、電場強度とミニバンド換算有効質量によって決定 


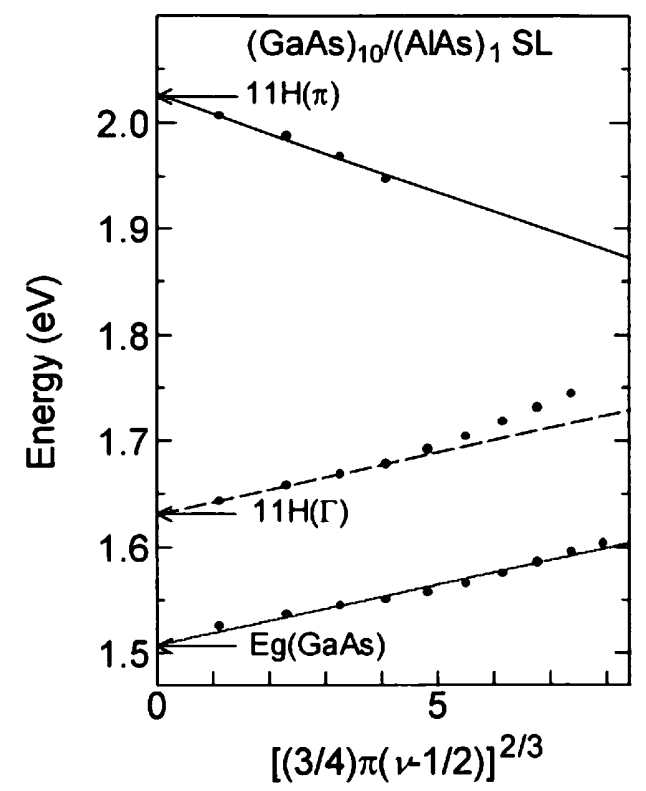

Fig. 10 Energies of the extrema of the Franz-Keldysh oscillations of the $(\mathrm{GaAs})_{10} /(\mathrm{AlAs})_{1}$ superlattice shown in Fig. 8 as a function of $[(3 / 4) \pi(v-1 / 2)]^{2 / 3}$ based on Eq. (8).

される。したがって、Franz-Keldysh 振動の解析から、ミ ニバンド有効質量を評価することが原理的に可能である。

Fig. 10 は、式 (8)にしたがって、Fig. 8 の (GaAs) $)_{10} /(\mathrm{AIAs})_{1}$ 超格子の光変調反射スペクトルで番号を付した FranzKeldysh振動をプロットした結果である ${ }^{21)}$ 。振動パターンが、 式 (8)の関係式で説明できることが明らかである。Fig. 10 におけるプロットの傾きが式 (8)の の $\theta$ に相当し、内部電場 強度 $F$ と換算有効質量 $\mu$ の 2 つパラメータが含まれる。

$\Gamma$ 点と $\pi$ 点の換算有効質量の導出方法について以下に述 べる。まず、GaAs 緩衝層からの Franz-Keldysh 振動（Fig. 10 では GaAs とラベル）に着目し、既知である GaAs の換 算有効質量 $\left(0.056 m_{0}\right)$ を用いて内部電場を見積もる。次に、 GaAs 緩衝層での電場強度が超格子のミニバンド状態にも 適用できると仮定し、超格子の Franz-Keldysh 振動から 点と $\pi$ 点におけるミニバンド換算有効質量を評価する。尚、 この内部電場に関する仮定は、試料がアンドープであるた めに、表面空乏層の長さは数 $\mu \mathrm{m}$ 程度であり、超格子の総 膜厚（約 $0.6 \mu \mathrm{m}$ ) より十分に長いので妥当なものである。 この解析から、内部電場強度が $15 \mathrm{kV} / \mathrm{cm} 、 \Gamma$ 点ミニバンド 換算有効質量が $0.054 \pm 0.010 m_{0} 、 \pi$ 点ミニバンド換算有効 質量が-0.018 $\pm 0.004 m_{0}$ (負の有効質量) と見積もられる。 Fig. 7 のミニバンド分散関係から計算した換算有効質量 は、 $\Gamma$ 点で $0.063 m_{0} 、 \pi$ 点で $-0.014 m_{0}$ であり、上記の評価 結果と誤差範囲の中で一致している。このように、ML 制 御超格子では、1原子層という極限層厚の障壁層を有する $(\mathrm{GaAs})_{10} /(\mathrm{AIAs})_{1}$ 超格子において、ミニバンド構造のミニバ
ンド幅とミニバンド有効質量を実験的に決定することがで きる。

超格子を素子として応用する場合、電場（バイアス電 圧）を印加する必要がある。電場下でのミニバンド状態の 詳細については、超格子の提案以来、長年にわたって未解 決のままであったが、1988 年にワニエ・シュタルク局在 (Wannier-Stark localization) という明確な解釈と実験結果が 報告された ${ }^{26,27)}$ 。ワニエ・シュタルク局在を概略的に述べ れば、ミニバンド構造を形成するための量子井戸間の共鳴 トンネル効果が静電ポテンシャルによって破綻し、電子. 正孔包絡関数が局在化する現象である。また、エネルギー 面では、ミニバンドが $e F D$ のネルギー間隔に分裂した（量 子化された）シュタルク階段状態 (Stark-ladder state) とな る。この現象は、波動関数と固有エネルギーの制御という 意味において非常にドラマティックなものであり、1962 年 に Wannier がバルク半導体のブロッホ電子を対象に提案し たが ${ }^{28)}$ 、超格子において初めて実証され、物性と応用の両 面において盛んに研究が行われてきた ${ }^{29)}$ 。また、ワニエ・シュ タルク局在状態の動的過程である局在波束のコヒーレント 振動は、テラヘルッ領域のブロッホ振動（Bloch oscillation： $e F D / h$ の振動数) に相当する。1993 年に、フェムト秒パル スレーザーを用いた超高速分光の実験によって、ブロッホ 振動に起因するテラヘルツ電磁波が初めて観測された ${ }^{30)}$ 。 ブロッホ振動は、周波数可変テラヘルツ電磁波源（振動数 が電場強度に比例する）として注目を集めている。また、 筆者らは、ミニバンド状態の励起子量子ビートからブロッ ホ振動への移行過程について詳細な研究成果を報告してい る $^{31)}$ 。

\section{5. おわりに}

以上において、MBE 法による超格子構造の精密制御（ML 制御)、及び、ML 制御 GaAs / AlAs 超格子の折り返し LA フォ ノンモードと電子・正孔ミニバンド構造に関する光物性研 究の成果について解説した。人工物質の物性研究において、 構造の制御性は最も重要な要因であり、制御性が不十分な 試料を対象としてどれほど精密に研究を行っても真理に到 達することができない。ある場合は、間違った解釈さえ生 じることがある。本稿で述べた ML 制御超格子の研究は、「精 密制御が、いかに本質的な物性研究を生み出すか」という ことの典型例であり、また、そのマイルストーンと言える。 どのような物質の研究においても、「ものづくりの精密さ」 が研究を飛躍させる最大のキーポイントであり、そのため のプロセス技術が今後さらに重要なものとなる。本稿が、 その参考の一つとなれば望外の喜びである。

\section{謝 辞}

本稿で述べた MBE 法によるモノレイヤー制御超格子の 結晶成長に関する研究は、山田科学振興財団より 1982 年に 
関西学院大学理学部に寄贈された MBE 装置を用いて行わ れたものである。さらに、1982 年〜 1986 年の 5 年間、山 田科学振興財団から MBE 装置の運営費を補助していたた いた。過去を振り返って、山田科学振興財団からの厚いご 支援に、心から感謝の意を表します。

\section{引用文献}

1) L. Esaki and R. Tsu: IBM J. Res. Dev. 14 (1970) 61-65.

2) 総説として、超格子へテロ構造デバイス、江崎玲於奈監修、 榊裕之編、工業調査会、1988.

3）総説として、E. L. Ivchenko and G. Pikus: “Superlattices and Other Heterostructures" , Springer, 1995.

4) J. H. Neave, B. A, Joyce: P. J. Dowson, and N. Norton: Appl. Phys. A 31 (1983) 1-8.

5) N. Sano, H. Kato, M. Nakayama, S. Chika, and H. Terauchi: Jpn. J. Appl. Phys. 23 (1984) L640-L641.

6) H. Terauchi, S. Sekimoto, K. Kamigaki, H. Sakashita, N. Sano, H. Kato, and M. Nakayama: J. Phys. Soc. Jpn. 54 (1985) 4576-4585.

7) 中山正昭 : 固体物理 22 (1987) 383-391.

8) M. Nakayama, K. Kubota, T. Kanata, H. Kato, S. Chika, and N. Sano: Jpn. J. Appl. Phys. 24 (1985) 1331-1334.

9) R. Loudon: Adv. Phys. 13 (1964) 423-482.

10) C. Colvard, R. Merlin, M. V. Klein, and A. C. Gossard: Phys. Rev. Lett. 45 (1980) 298-301.

11) M. Nakayama, K. Kubota, H. Kato, S. Chika, and N. Sano: Solid State Commun. 53 (1985) 493-495.

12) S. M. Rytov: Sov. Phys. Acoust. 2 (1956) 68-80.

13) A. Yamamoto, T. Mishina, Y. Masumoto, and M. Nakayama: Phys. Rev. Lett. 73 (1994) 740-743.

14) K. Mizoguchi, T. Furuichi, O. Kojima, M. Nakayama, S. Saito, A. Shouji, and K. Sakai: Appl. Phys. Lett. 87 (2005) 093102-1-093102-3.
15) M. Nakayama, K. Mizoguchi, O. Kojima, T. Furuichi, A. Mizumoto, S. Saito, A. Shouji, and K. Sakai: Phys. Status Solidi A 204 (2007) 518-521.

16) M. Nakayama, S. Ito, K. Mizoguchi, S. Saito, and K. Sakai: Appl. Phys. Express 1 (2008) 012004-1--012004-3.

17) H. Takeuchi, S. Asai, S. Tsuruta, and M. Nakayama: Appl. Phys. Lett. 100 (2012) 242107-1--242107-4.

18) G. Bastard: Phys. Rev. B 24 (1981) 5693-5697.

19) I. Tanaka, M. Nakayama, H. Nishimura, K. Kawashima, and K. Fujiwara: Phys. Rev. B 48 (1993) 2787-2790.

20) M. Nakayama, M. Ando, I. Tanaka, H. Nishimura, H. Schneider, and K. Fujiwara: Phys. Rev. B 51 (1995) 4236-4241.

21) M. Nakayama, T. Nakanishi, K. Okajima, M. Ando, and H. Nishimura: Solid State Commun. 102 (1997) 803-807.

22) J. L. Shay: Phys. Rev. B 2 (1970) 803-807.

23) D. E. Aspnes: Surf. Sci. 37 (1973) 418-442.

24) D. F. Nelson, R. C. Miller, C. W. Tu, and K. Sputz: Phys. Rev. B 36 (1987) 8063-8070.

25) D. E. Aspnes and A. A. Studna: Phys. Rev. B 7 (1973) 4605-4625.

26) E. E. Mendez, F. Agulló-Rueda, and J. M. Hong: Phys. Rev. Lett. 60 (1988) 2426-2429.

27) P. Voisin, J. Bleuse, C. Bouche, S. Gaillard, C. Alibert, and A. Regreny: Phys. Rev. Lett. 61 (1988) 1639-1642.

28) G. H. Wannier: Rev. Mod. Phys. 34 (1962) 645-655.

29) 解説として、M. Nakayama: “Optical Properties of Low Dimensional Materials” ed. by T. Ogawa and Y. Kanemitsu, World Scientific, 1995, pp.147-201.

30) C. Waschke, H. G. Roskos, R. Scweidier, K. Leo, H. Kurz, and K. Köhler: Phys. Rev. Lett. 70 (1993) 3319-3323.

31) T. Hasegawa, K. Mizoguchi, and M. Nakayama: Phys. Rev. B 76 (2007) 115323-1--115323-6. 